ARTICLE

https://doi.org/10.1038/s41467-019-14121-1

\title{
Synergistic effect of quinary molten salts and ruthenium catalyst for high-power-density lithium- carbon dioxide cell
}

Kyungeun Baek ${ }^{1,2}$, Woo Cheol Jeon ${ }^{1,2}$, Seongho Woo ${ }^{1}$, Jin Chul Kim¹, Jun Gyeong Lee ${ }^{1}$, Kwangjin An (1) ${ }^{1 *}$, Sang Kyu Kwak (i) ${ }^{1 \star} \&$ Seok Ju Kang (i) ${ }^{1 \star}$

With a recent increase in interest in metal-gas batteries, the lithium-carbon dioxide cell has attracted considerable attention because of its extraordinary carbon dioxide-capture ability during the discharge process and its potential application as a power source for Mars exploration. However, owing to the stable lithium carbonate discharge product, the cell enables operation only at low current densities, which significantly limits the application of lithium-carbon dioxide batteries and effective carbon dioxide-capture cells. Here, we investigate a high-performance lithium-carbon dioxide cell using a quinary molten salt electrolyte and ruthenium nanoparticles on the carbon cathode. The nitrate-based molten salt electrolyte allows us to observe the enhanced carbon dioxide-capture rate and the reduced dischargecharge over-potential gap with that of conventional lithium-carbon dioxide cells. Furthermore, owing to the ruthernium catalyst, the cell sustains its performance over more than 300 cycles at a current density of $10.0 \mathrm{~A} \mathrm{~g}^{-1}$ and exhibits a peak power density of $33.4 \mathrm{~mW} \mathrm{~cm}-2$.

\footnotetext{
${ }^{1}$ Department of Energy Engineering, School of Energy and Chemical Engineering, Ulsan National Institute of Science and Technology (UNIST), Ulsan 44919, Republic of Korea. ${ }^{2}$ These authors contributed equally: Kyungeun Baek, Woo Cheol Jeon *email: kjan@unist.ac.kr; skkwak@unist.ac.kr; sjkang@unist.ac.kr
} 
echargeable alkali metal-gas cells have attracted considerable interest for high-energy-density storage systems because of their ultralightweight air cathodes such as $\mathrm{O}_{2}$ and $\mathrm{CO}_{2}$ gases ${ }^{1-8}$. When directly using the lightest $\mathrm{Li}$ metal anode, a specific energy of $3860 \mathrm{mAh} \mathrm{g}^{-1}$ can be achieved with an $\mathrm{O}_{2}$ cathode, which undoubtedly solves the energy constraints of the current Li-ion batteries ${ }^{1-3}$. However, an unwanted side reaction elicited by the aprotic electrolyte and the carbon current collector significantly erodes the $\mathrm{Li}-\mathrm{O}_{2}$ battery performance ${ }^{9-11}$. This limitation has ultimately led to intensive research on electrochemically inert electrolytes and novel cathode materials. Among the many innovative proposed material candidates, the nitrate-based molten salt electrolyte and the porous Au cathode exhibited a promising oxygen-evolution reaction (OER)/oxygenreduction reaction (ORR) ratio, measured by differential electrochemical mass spectrometry (DEMS) ${ }^{12,13}$. The key finding behind these studies is that the stable components against the $\mathrm{Li}-\mathrm{O}_{2}$ electrochemical reaction effectively minimize the detrimental side reactions and allow operation of the battery cycle without significant degradation.

However, there is still one cumbersome problem: the accumulation of the parasitic product $\mathrm{Li}_{2} \mathrm{CO}_{3}$ during the discharge-charge processes ${ }^{9,14}$. In particular, it is well known that the stable nature of $\mathrm{Li}_{2} \mathrm{CO}_{3}$ inevitably induces dead space in the cathode side, which eventually causes decreased cycle ability and increased charge potential. In order to cope with this fatal issue, paradoxically, researchers have successfully proposed a $\mathrm{Li}-\mathrm{CO}_{2}$ cell and suggested the importance of its application as both a rechargeable secondary battery and $\mathrm{CO}_{2}$ capture device to retard global warming $5,15-22$. The proposed $\mathrm{CO}_{2}$ reduction reaction $\left(\mathrm{CO}_{2} \mathrm{RR}\right)$ in the $\mathrm{Li}-\mathrm{CO}_{2}$ battery is based on the following electrochemical reaction: $4 \mathrm{Li}^{+}+3 \mathrm{CO}_{2}+4 \mathrm{e}^{-} \rightarrow 2 \mathrm{Li}_{2} \mathrm{CO}_{3}+\mathrm{C}(2.80$ $\mathrm{V}$ vs. $\left.\mathrm{Li} / \mathrm{Li}^{+}\right)^{5}$. During the galvanostatic discharge process, the $\mathrm{Li}-\mathrm{CO}_{2}$ cell needs $4 / 3$ electron to capture a single $\mathrm{CO}_{2}$ gas molecule and produces the $2 \mathrm{Li}_{2} \mathrm{CO}_{3}$ and amorphous carbon on the cathode side, indicating that the electron-to- $\mathrm{CO}_{2}$ ratio $\left(\mathrm{e}^{-} /\right.$ $\mathrm{CO}_{2}$ ) is 1.33 .

Although the $\mathrm{Li}-\mathrm{CO}_{2}$ cell effectively captures $\mathrm{CO}_{2}$ gas during the discharge process, the high charge overpotential caused by the insulating and insoluble characteristics of $\mathrm{Li}_{2} \mathrm{CO}_{3}$ in the aprotic electrolyte should be reduced to prevent the severe parasitic reaction $7,15,16,23$. Therefore, most recent research on $\mathrm{Li}-\mathrm{CO}_{2}$ cells has focused on developing air-breathing cathodes such as metal catalysts, mediators, and metal oxide materials for reducing the charge overpotential and increasing the cycle ability $8,18,24-28$. However, because of the sluggish electron transfer in the $\mathrm{Li}_{2} \mathrm{CO}_{3}$ insulator, most of the reported studies investigated $\mathrm{Li}-\mathrm{CO}_{2}$ cells with mild current densities (Supplementary Table 1), which are not appropriate for high-performance battery applications, the limiting factor for the $\mathrm{CO}_{2}$ capture rate; thus, enhancement of the rate performance certainly is advantageous to facilitate practical future battery and $\mathrm{CO}_{2}$ storage applications of $\mathrm{Li}-\mathrm{CO}_{2}$ cell.

Here, we report the demonstration of a high-power-density $\mathrm{Li}-\mathrm{CO}_{2}$ cell based on a quinary-molten salt electrolyte containing $\mathrm{Ru}$ nanoparticles on the carbon cathode. The employed nitrate-based quinary-molten salt allows high-temperature operation of the $\mathrm{Li}-\mathrm{CO}_{2}$ battery, which reduces the discharge-charge overpotential. Moreover, the presence of $\mathrm{Ru}$ nanoparticles on the carbon cathode prepared by the Joule heating method further improves the electrochemical characteristics of the $\mathrm{Li}-\mathrm{CO}_{2}$ cell, resulting in a long cycle life of more than 300 cycles at a high-current density of $10.0 \mathrm{~A} \mathrm{~g}^{-1}$. In addition, a high-power-density of $33.4 \mathrm{~mW} \mathrm{~cm}^{-2}$ is successfully achieved; this is a potentially decisive factor for next-generation high-rate rechargeable $\mathrm{Li}-\mathrm{CO}_{2}$ batteries and efficient $\mathrm{CO}_{2}$ capture electrochemical cells.

\section{Results}

Aprotic electrolyte-based $\mathrm{Li}-\mathrm{CO}_{2}$ cell. Following recent $\mathrm{Li}-\mathrm{CO}_{2}$ battery studies (Supplementary Table 1), we first fabricated a cell consisting of a Li metal anode, carbon cathode, and $1 \mathrm{M}$ lithium bis (trifluoromethanesulfonyl)imide (LiTFSI) in tetraethylene glycol dimethyl ether (TEGDME) electrolyte to monitor the $\mathrm{CO}_{2} \mathrm{RR}$ during the galvanostatic discharge process by using pressure decay measurement. As shown in Fig. 1a, the linear drop of consumed $\mathrm{CO}_{2}$ molecules indicates that the value of the electrons per $\mathrm{CO}_{2}$ ratio is $\sim 1.32$, which agrees well with the previously proposed discharge electrochemical reaction of $4 \mathrm{Li}^{+}+3 \mathrm{CO}_{2}+4 \mathrm{e}^{-} \rightarrow 2 \mathrm{Li}_{2} \mathrm{CO}_{3}+\mathrm{C}$ $\left(2.80 \mathrm{~V} \text { vs. } \mathrm{Li} / \mathrm{Li}^{+}\right)^{5}$. In addition, the $\mathrm{C} 1 \mathrm{~s} \mathrm{X}$-ray photoelectron spectroscopy (XPS) spectra of a $1 \mathrm{mAh}$ discharged carbon cathode presented a strong peak at $290 \mathrm{eV}$ as shown in Fig. 1b, revealing the formation of $\mathrm{Li}_{2} \mathrm{CO}_{3}$ during the discharge process (Supplementary Fig. 1$)^{8}$. However, the amount of $\mathrm{CO}_{2}$ evolution during the charge process measured by DEMS in Fig. 1c shows that the electrochemical reaction clearly does not follow the discharge reaction of $4 \mathrm{Li}^{+}+3 \mathrm{CO}_{2}+4 \mathrm{e}^{-} \rightarrow 2 \mathrm{Li}_{2} \mathrm{CO}_{3}+\mathrm{C}\left(2.80 \mathrm{~V} \text { vs. } \mathrm{Li}^{2} / \mathrm{Li}^{+}\right)^{5}$. In particular, the different electrochemical reactions and multiple charging plateaus during the charging process have been reported ${ }^{5,7}$. For instance, Qiao et al. showed that there are several different pathways to decompose the stable $\mathrm{Li}_{2} \mathrm{CO}_{3}{ }^{5}$. Depending on the applied current and charging voltage, the electrons per $\mathrm{CO}_{2}$ can be either 1.5 or $2.0 \mathrm{e}^{-} / \mathrm{CO}_{2}$ during the charging process, implying an irreversible electrochemical reaction in the $\mathrm{Li}-\mathrm{CO}_{2}$ battery. In addition, Zhang et al. observed multiple plateaus with fluctuating evolution rates of $\mathrm{CO}_{2}$ gas during the charging process ${ }^{7}$. Nevertheless, to further understand this irreversible electrochemical reaction, we employed a carbon isotope $\left({ }^{13} \mathrm{C}\right)$ cathode and performed linear-sweep voltammetry with the corresponding DEMS measurements (Supplementary Fig. 2). Although both ${ }^{12} \mathrm{CO}_{2}$ and ${ }^{13} \mathrm{CO}_{2}$ (mass weight of 45) are evolved at the same potential, the trace of the mass weight of 45 may not originate from ${ }^{13} \mathrm{CO}_{2}$ because a previous study clearly showed that the decomposition of TEGDME generates fragment- 45 owing to the generation of superoxide radicals during the decomposition of $\mathrm{Li}_{2} \mathrm{CO}_{3}$; these results are in good agreement with ours ${ }^{29}$. In addition, low peak power density of $2.9 \mathrm{~mW} \mathrm{~cm}^{-2}$ (Fig. 1d) and the evolution of $\mathrm{H}_{2}$ and $\mathrm{CO}_{2}$ gases at the potentials of 4.2 and $4.7 \mathrm{~V}$ in a fresh cell before discharging (Supplementary Fig. 3) clearly reveal further disadvantages of using aprotic solvent, which ultimately leads us to attempt an alternative electrolyte for highperformance $\mathrm{Li}-\mathrm{CO}_{2}$ cell. It is noted that the $\mathrm{H}_{2}$ evolution from the fresh cell is presumably due to the parasitic reaction between the aprotic electrolyte and the Li metal ${ }^{30,31}$.

Molten salt-based $\mathrm{Li}-\mathrm{CO}_{2}$ cell. In order to reduce the overpotential at high-current densities during the charge process, we prepared a cell with nitrate-based quinary-molten salt for an aprotic solvent-free electrolyte. The low eutectic melting temperature of the quinary-molten electrolyte allows us not only to perform a systematic study of the $\mathrm{Li}_{2} \mathrm{CO}_{3}$ decomposition process in a wide temperature range from 100 to $150^{\circ} \mathrm{C}$ but also to potentially use for $\mathrm{CO}_{2}$ capture from the high-temperature power plant flue gas (Supplementary Fig. 4) ${ }^{32}$. As shown in the galvanostatic discharge-charge profiles in Fig. 2a, we observed that the operating temperature plays a critical role in reducing the discharge and charge overpotential of the $\mathrm{Li}-\mathrm{CO}_{2}$ battery. For instance, the $\mathrm{Li}-\mathrm{CO}_{2}$ cell at $150{ }^{\circ} \mathrm{C}$ exhibits a discharge-charge potential gap of $0.7 \mathrm{~V}$, whereas the cell at $100^{\circ} \mathrm{C}$ exhibits an $\sim 2.1 \mathrm{~V}$ potential gap. In addition, the multiple charging plateaus may be due to the parasitic reaction between the discharge product and the carbon surface, which we will discuss later in Fig. 4. The pressure-drop measurement and Li1s XPS analysis further verify the electrochemical reaction of $\mathrm{Li}-\mathrm{CO}_{2}$ cell in the nitrate-based 


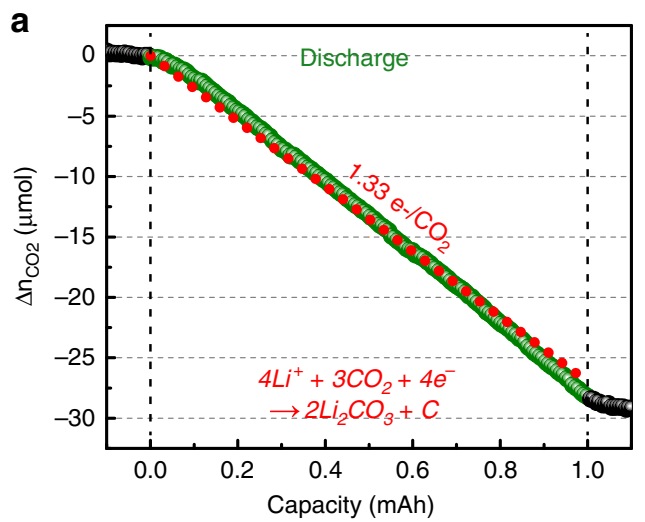

C

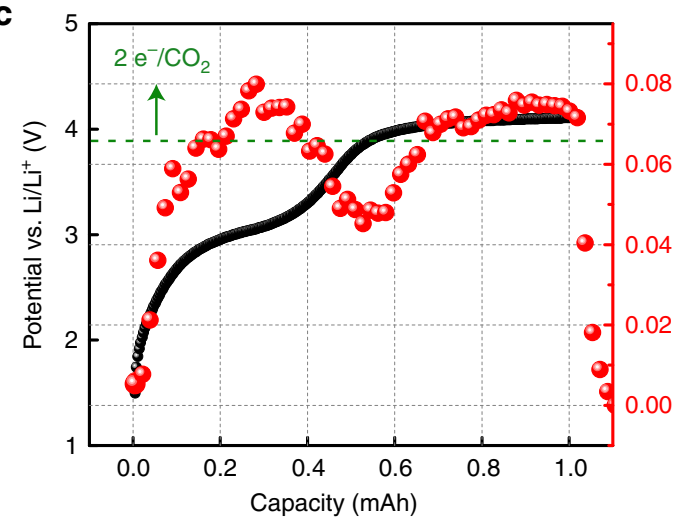

b

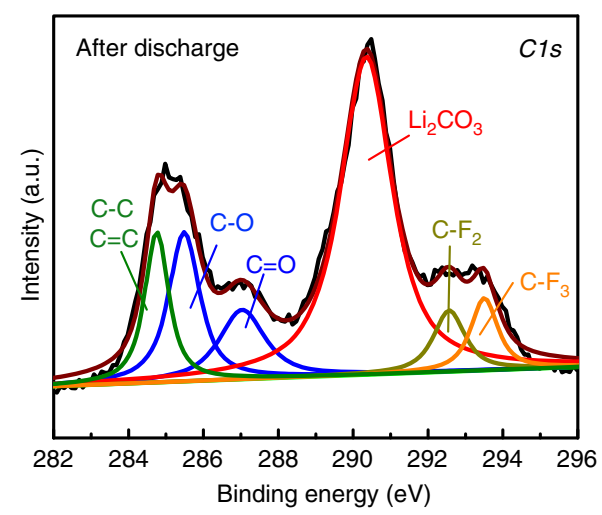

d

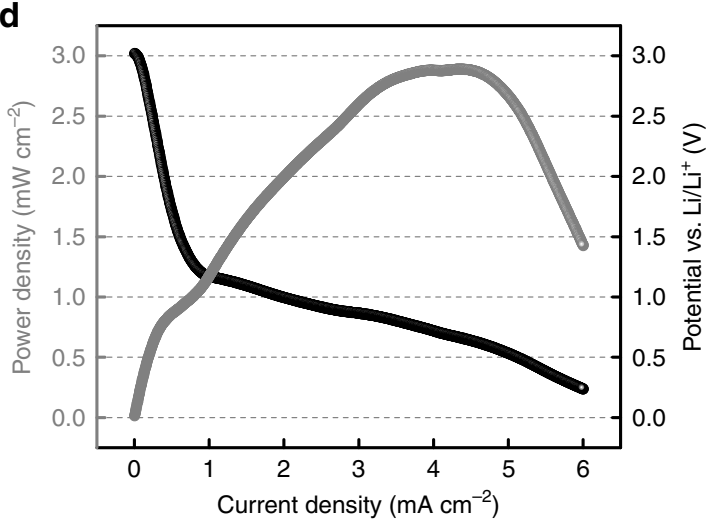

Fig. 1 Electrochemical characterizations of $\mathbf{L i}-\mathrm{CO}_{2}$ cell by using an aprotic electrolyte. a Plot of $\mathrm{CO}_{2}$ gas consumption during the galvanostatic discharge $(200 \mu \mathrm{A})$. The $\mathrm{Li}-\mathrm{CO}_{2}$ cell contains $1 \mathrm{M} \mathrm{LiTFSI}$ in TEGDME electrolyte. The red dots indicate the ideal electron-to- $\mathrm{CO}_{2}$ ratio of 1.33 . b C1s XPS result of the carbon cathode after 1-mAh discharge. c Galvanostatic charge plot and the corresponding DEMS results of the Li-CO ${ }_{2}$ cell containing $1 \mathrm{M}$ LiTFSI in TEGDME electrolyte. The green dots correspond to the theoretical amount of $\mathrm{CO}_{2}$ evolution. $\mathbf{d}$ Polarization and power-density curves of $1 \mathrm{M}$ LiTFSI in TEGDME with a scan rate of $0.01 \mathrm{~mA} \mathrm{~s}^{-1}$.

electrolyte (Fig. 2b and Supplementary Fig. 5). Although we observed a strong signal at $55.3 \mathrm{eV}$ for the $\mathrm{Li}_{2} \mathrm{CO}_{3}$ compound, the measured electron-to- $\mathrm{CO}_{2}$ ratio of 2.0 is in contrast to the aprotic electrolyte-based $\mathrm{Li}-\mathrm{CO}_{2}$ cell in Fig. 1. This different electrochemical reaction can be explained by the previous nitrate molten electrolyte-based $\mathrm{Li}-\mathrm{O}_{2}$ battery studies because the regeneration of $\mathrm{NO}_{3}{ }^{-}$from $\mathrm{NO}_{2}{ }^{-}$leads to alter the conventional electrochemical reaction of $\mathrm{Li}-\mathrm{O}_{2}$ cell ${ }^{33-35}$. In the case of nitrate molten salt in $\mathrm{Li}-\mathrm{CO}_{2}$ cell, N1s XPS analysis in Fig. 2c shows the existence of $\mathrm{NO}_{2}$ compound after the discharge process, which is evidence that the nitrate anion is involved in the electrochemical reaction and altered the electrochemical reaction and discharge potential of $\mathrm{Li}-\mathrm{CO}_{2}$ cell (Supplementary Table 2, Supplementary Figs. 6-7) ${ }^{33-35}$. However, during the charging process, the DEMS results in Fig. $2 \mathrm{~d}$ found that the $\mathrm{CO}_{2}$ evolution rates varied with operating temperature. The $\mathrm{CO}_{2}$ evolution rate increases with decreasing operating temperature, ranging from $\sim 2.0 \mathrm{e}^{-} / \mathrm{CO}_{2}$ at $100^{\circ} \mathrm{C}$ to $\sim 6.0 \mathrm{e}^{-} / \mathrm{CO}_{2}$ at $150^{\circ} \mathrm{C}$. The value of $0.02 \mu \mathrm{mol} \mathrm{min}^{-1}$ at $150^{\circ} \mathrm{C}$ during the galvanostatic charging process indicates that the electrochemical reaction is irreversible and different from the discharge process. In addition, the shifted $\mathrm{Li}_{2} \mathrm{CO}_{3}$ peak and the remaining $\mathrm{NO}_{2}$ compound in the XPS analysis after discharge and charge cycles at $150^{\circ} \mathrm{C}$ suggests the formation of a new adduct during the charging process that significantly reduces $\mathrm{CO}_{2}$ evolution (Fig. 2e-f). It is noted that the molten salt electrolyte exhibits monotonically increasing $\mathrm{CO}_{2}$ rate that may be due to the enhanced $\mathrm{CO}_{2}$ solubility at high temperature. We observed a sharp increase in the gas evolution after $\mathrm{CO}_{2}$ gas saturation by using a deep discharged cell that also provides electron-to- $\mathrm{CO}_{2}$ ratio in the molten electrolyte (Supplementary Fig. 8). Furthermore, we performed linear-sweep voltammetry and carried out the galvanostatic charging process with the corresponding DEMS measurements at $100^{\circ} \mathrm{C}$ to confirm the contribution of $\mathrm{CO}_{2}$ evolution by using the ${ }^{13} \mathrm{CO}_{2}{ }^{12} \mathrm{C}$ and ${ }^{12} \mathrm{CO}_{2}{ }^{13} \mathrm{C}$ systems (Supplementary Fig. 9). Although we observed evidence of carbon decomposition in the linear-sweep voltammetry results for both systems, the galvanostatic charging process with the corresponding DEMS measurements showed marginal $\mathrm{CO}_{2}$ evolution from the carbon cathode, which indicates that $\mathrm{CO}_{2}$ evolution predominantly occurs from $\mathrm{Li}_{2} \mathrm{CO}_{3}$ decomposition at $100^{\circ} \mathrm{C}$ (Supplementary Fig. 10).

Reaction mechanism of $\mathrm{Li}_{2} \mathrm{CO}_{3}$ decomposition. Although the exact electrochemical reaction remains unclear, we examined the $\mathrm{Li}_{2} \mathrm{CO}_{3}$ decomposition mechanism by the density functional theory (DFT) calculation to explain the variation of generating the amount of $\mathrm{CO}_{2}$ depending on the operating temperature (i.e., $100^{\circ} \mathrm{C}$ and $150^{\circ} \mathrm{C}$ ) of $\mathrm{Li}-\mathrm{CO}_{2}$ cells (see the "Supplementary Methods" section and Supplementary Fig. 11). The $\mathrm{Li}_{2} \mathrm{CO}_{3}$ decomposition mechanism under implicit quinary-molten salt condition was divided into the electrochemical reaction step, where $\mathrm{Li}$ ion is extracted by the charge potential, and the thermodynamic reaction step, where the carbonate on the surface participates in the reaction. We compared the $\mathrm{Li}$ extraction energy and activation energy of $\mathrm{CO}_{2}$ formation reaction by $\mathrm{NO}_{2}{ }^{-}$ to determine the reaction priority (Supplementary Fig. 12). Since the $\mathrm{Li}$ extraction energy (i.e., 2.79 and $3.24 \mathrm{eV}$ for the first and second Li extraction, respectively) was lower than the activation 
a
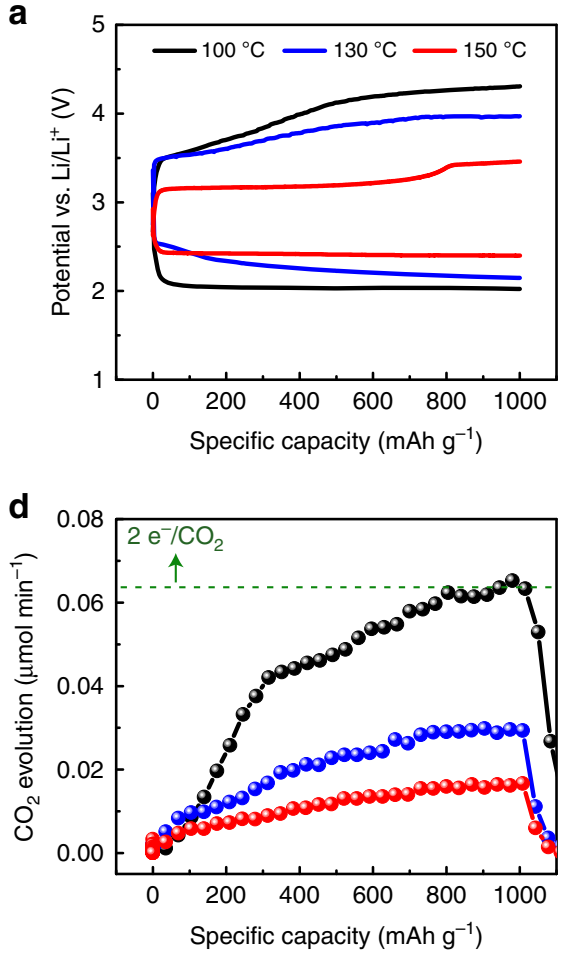

b

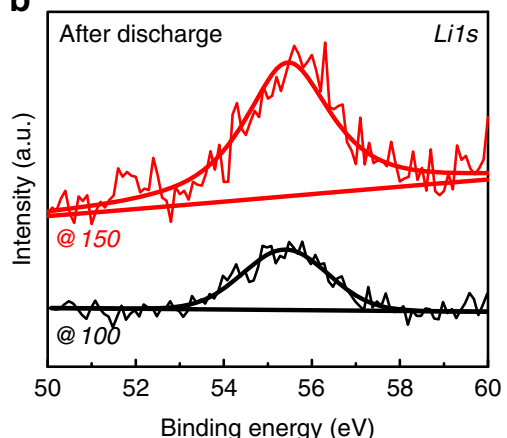

e

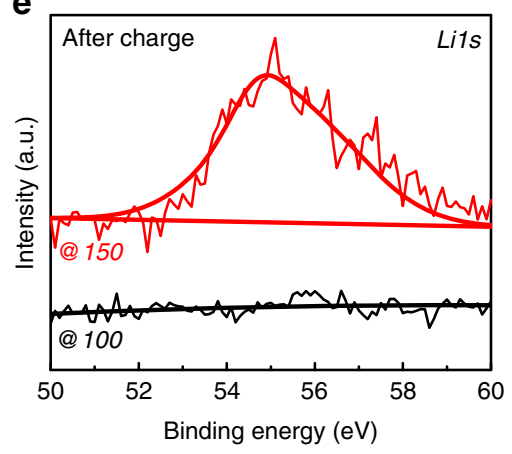

C

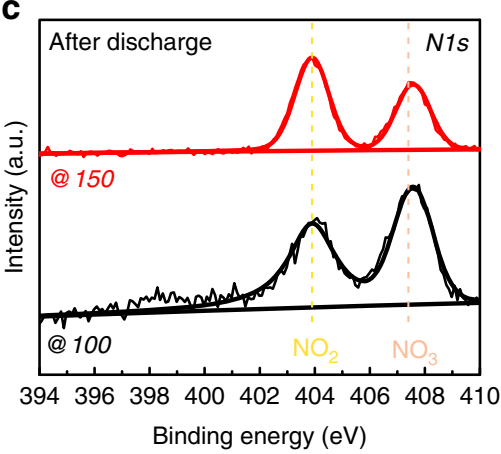

f

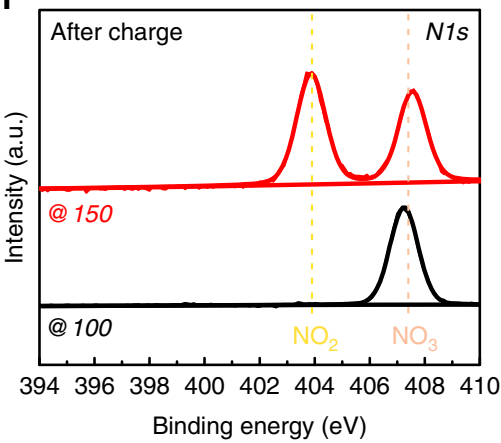

Fig. 2 Characterizations of $\mathbf{L i}-\mathrm{CO}_{\mathbf{2}}$ battery by using quinary-molten salt electrolyte. a Galvanostatic discharge and charge profiles of a Li-CO $\mathrm{C}_{2}$ battery with quinary-molten salt electrolyte at different operating temperatures $\left(100-150^{\circ} \mathrm{C}\right)$ at current density of $0.4 \mathrm{~A} \mathrm{~g}^{-1}$. b-c High-resolution XPS Li1s (b) and $\mathrm{N} 1 \mathrm{~s}$ (c) spectra of the carbon cathode after $1000 \mathrm{mAh} \mathrm{g}^{-1}$ discharge. d DEMS result of the $\mathrm{Li}_{-} \mathrm{CO}_{2}$ cell containing quinary-molten salt electrolyte at different operating temperatures during charge process in $\mathbf{a}$. e-f The green dots correspond to the theoretical amount of $\mathrm{CO}_{2}$ evolution. High-resolution XPS Li1s (e) and N1s (f) spectra of the carbon cathodes after $1000 \mathrm{mAh} \mathrm{g}^{-1}$ discharge and charge processes. The black and red lines indicate the results at operating temperatures of 100 and $150^{\circ} \mathrm{C}$, respectively.

energy of $\mathrm{CO}_{2}$ formation reaction (i.e., $4.01 \mathrm{eV}$ ), it was predicted that the $\mathrm{CO}_{2}$ formation reaction could occur after the Li extraction reaction. Thus, we suggest path a $\left(\mathrm{Li}_{2} \mathrm{CO}_{3}+\mathrm{NO}_{2}{ }^{-} \rightarrow 2 \mathrm{Li}^{+}+\right.$ $\mathrm{CO}_{2}+\mathrm{NO}_{3}{ }^{-}+2 \mathrm{e}^{-}$) for the decomposition mechanism of $\mathrm{Li}_{2} \mathrm{CO}_{3}$ at $100{ }^{\circ} \mathrm{C}$ (Fig. 3a-c). In path a, after the two $\mathrm{Li}$ atoms were extracted, carbonate ion reacted with $\mathrm{NO}_{2}{ }^{-}$to produce $\left[\mathrm{CO}_{3} \mathrm{NO}_{2}\right]^{-}$ at the first intermediate state (IM1). From IM1 to IM2, a bridge $\mathrm{O}$ atom bonded to $\mathrm{C}$ and $\mathrm{N}$ atoms was moved to form $\mathrm{NO}_{3}{ }^{-}$and produce $\mathrm{CO}_{2}$. Then, $\mathrm{CO}_{2}$ was desorbed from the surface in the final state (FS). The full-charge N1s XPS analysis showed no peak of $\mathrm{NO}_{2}{ }^{-}$because of the generation of $\mathrm{NO}_{3}{ }^{-}$as we conjectured (Fig. 2f). At $150^{\circ} \mathrm{C}$, as shown in Fig. $3 \mathrm{~b}-\mathrm{c}$, the $\mathrm{Li}_{2} \mathrm{CO}_{3}$ decomposition mechanism initially followed the same reaction process of path a. However, after $\mathrm{CO}_{2}$ and $\mathrm{NO}_{3}{ }^{-}$are formed on the surface (IM2') in path b $\left(2 \mathrm{Li}_{2} \mathrm{CO}_{3}+\mathrm{NO}_{2}{ }^{-} \rightarrow 4 \mathrm{Li}^{+}+\mathrm{C}_{2} \mathrm{O}_{5}{ }^{2-}+\right.$ $\left.\mathrm{NO}_{3}{ }^{-}+2 \mathrm{e}^{-}\right)$, $\mathrm{CO}_{2}$ could react further with the adjacent carbonate to form $\mathrm{C}_{2} \mathrm{O}_{5}{ }^{2-}$ (FS'). Separately, the unstable carbonate could react with the adjacent carbonate to form $\mathrm{C}_{2} \mathrm{O}_{6}{ }^{2-}$ (FS") in path $\mathrm{c}\left(2 \mathrm{Li}_{2} \mathrm{CO}_{3} \rightarrow 4 \mathrm{Li}^{+}+\mathrm{C}_{2} \mathrm{O}_{6}{ }^{2-}+2 \mathrm{e}^{-}\right)$, where $\mathrm{NO}_{2}{ }^{-}$was not used as the reactant in the $\mathrm{Li}_{2} \mathrm{CO}_{3}$ decomposition mechanism. The three paths in the reaction mechanisms predicted to be occurred at $150^{\circ} \mathrm{C}$ were consistent with experimental results, where $\mathrm{NO}_{2}{ }^{-}$and $\mathrm{NO}_{3}{ }^{-}$presented on the surface and a small amount of $\mathrm{CO}_{2}$ was released (Fig. $2 \mathrm{~d}-\mathrm{f}$ ). We speculated that the thermal energy at the higher temperature could promote the reactions of paths $b$ and $c$; the activation energies of the two mechanisms (i.e., $1.39 \mathrm{eV}$ for path $\mathrm{b}$ and $1.54 \mathrm{eV}$ for path $\mathrm{c}$ at $150^{\circ} \mathrm{C}$ ) were higher than the activation energy for the mechanism to produce $\mathrm{CO}_{2}$ gas (i.e., $0.99 \mathrm{eV}$ for path a at $100^{\circ} \mathrm{C}$ ). Interestingly, $\mathrm{CO}_{2}$ was favored in the adsorbed state considering the endothermic heat of reaction from IM2 to FS in path a without a transition state. This also could be a reason for $\mathrm{CO}_{2}$ to undergo the reaction step from IM2 to FS at $150^{\circ} \mathrm{C}$. All of the optimized configurations in each reaction mechanism are depicted in Supplementary Fig. 13. It should be noted that because the proposed pre-equilibrium electrochemical reactions are not the complete reaction mechanism of the charge process, the generation of the short-lived intermediate $\mathrm{C}_{2} \mathrm{O}_{6}{ }^{2-}$ produces new adducts, resulting in irreversible $\mathrm{CO}_{2}$ evolution at $150{ }^{\circ} \mathrm{C}$ in the DEMS measurements in Fig. 2.

Electrochemical performance of $\mathbf{L i}-\mathrm{CO}_{2}$ cell. To investigate the high-current performance of the quinary-molten salt electrolyte, we evaluated the galvanostatic discharge-charge characteristics of the $\mathrm{Li}-\mathrm{CO}_{2}$ cell under a current-density range of $1.0-20.0 \mathrm{~A} \mathrm{~g}^{-1}$ (Fig. 4a). As shown in the plots, the discharge-charge overpotentials were dominantly affected by the applied current densities. For instance, the $\mathrm{Li}-\mathrm{CO}_{2}$ battery at an applied current density of $1.0 \mathrm{~A} \mathrm{~g}^{-1}$ had the lowest discharge-charge potential gap of $1.0 \mathrm{~V}$, whereas that at an applied current of $20.0 \mathrm{~A} \mathrm{~g}^{-1}$ showed the highest potential gap of $1.7 \mathrm{~V}$ (Fig. 4b). Although the discharge-charge overpotential gap monotonically increases with increasing applied current density, the stable discharge-charge profiles at $20.0 \mathrm{~A} \mathrm{~g}^{-1}$ clearly suggest that the high-temperature operation of quinary-molten salt at $150^{\circ} \mathrm{C}$ efficiently enhances the rate performance of the $\mathrm{Li}-\mathrm{CO}_{2}$ battery, which is one of the desired battery characteristics and also has the advantage of capturing $\mathrm{CO}_{2}$ gas from power plants because the high-current density increases the $\mathrm{CO}_{2}$ capture rate (Supplementary Fig. 14). In addition, we observed a high peak power density of $19.7 \mathrm{~mW} \mathrm{~cm}^{-2}$ from the quinary-molten salt-based $\mathrm{Li}-\mathrm{CO}_{2}$ cell (Fig. 4c); this value is approximately seven times higher than that 

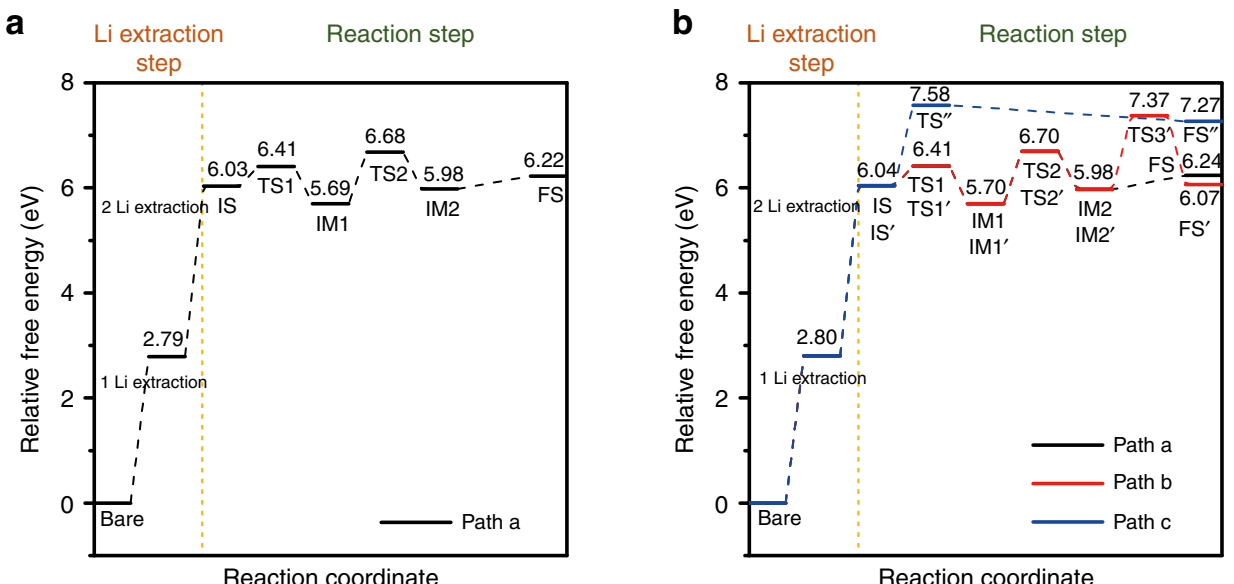

C

Reaction coordinate

Reaction coordinate Path a

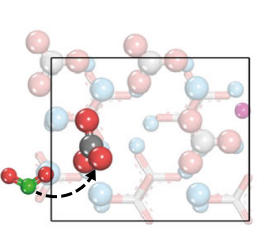

IS

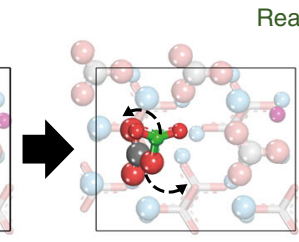

Reaction step
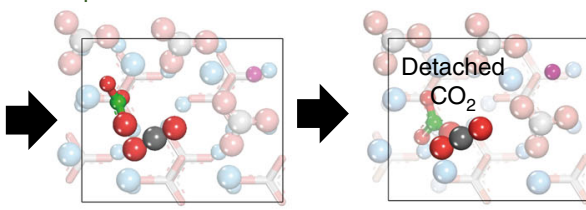

FS

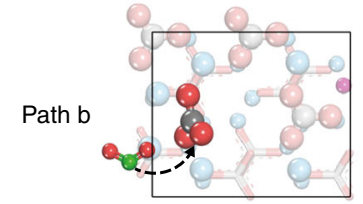

IS

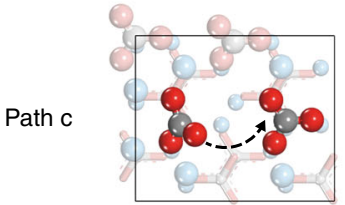

IS"
M1

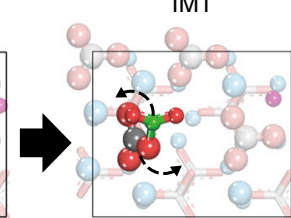

IM1'

IM2

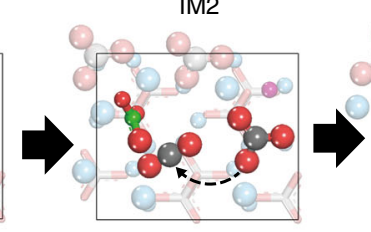

IM2'

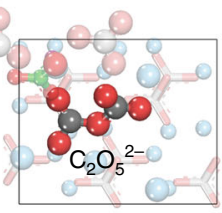

$\mathrm{FS}^{\prime}$

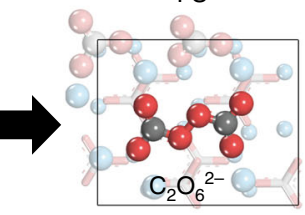

FS"

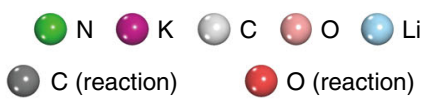

Fig. 3 Reaction mechanism of $\mathbf{L i}_{2} \mathbf{C O}_{3}$ decomposition. a Reaction coordinate of one possible path a to produce $\mathrm{CO}_{2}$ and $\mathrm{NO}_{3}{ }^{-}\left(\right.$black line) at $100{ }^{\circ} \mathrm{C}$. b Reaction coordinate of three plausible pathways (i.e., path a, path $b$ to produce $\mathrm{C}_{2} \mathrm{O}_{5}{ }^{2-}$ and $\mathrm{NO}_{3}{ }^{-}$(red line), and path $\mathrm{c}$ to produce $\mathrm{C}_{2} \mathrm{O}_{6}{ }^{2-}$ (blue line)) at $150^{\circ} \mathrm{C}$. c Optimized configurations on three plausible pathways for the reaction step corresponding to (a) and (b). IS, IM, and FS in each reaction mechanism represent the initial state, intermediate state, and final state, respectively. The yellow dotted line is the boundary between the Li extraction step and the reaction step, and the numbers represent the relative free energies based on those of bare surface in (a) and (b). Nitrogen, potassium, carbon, oxygen, and lithium atoms are colored in green, purple, light gray, pink, and sky blue. For a clear view, the carbon, oxygen, and lithium atoms, which participate in the reaction, are colored in dark gray, red, and blue. Arrow dotted lines represent the movement of molecules from state to state. For a clear view, the molecules, except reacting molecules, were made to be translucent in (c).

of the conventional $\mathrm{Li}-\mathrm{CO}_{2}$ battery with $1 \mathrm{M}$ LiTFSI in the TEGDME electrolyte (Fig. 1d). We also measured the power density with another ternary-molten salt $\left(37 \mathrm{~mol} \% \mathrm{LiNO}_{3}, 39 \mathrm{~mol} \% \mathrm{KNO}_{2}\right.$, and $24 \mathrm{~mol} \% \mathrm{CsNO}_{3}$ ) electrolyte at $150{ }^{\circ} \mathrm{C}$ (Supplementary Fig. 15). Although the peak power density of $16.2 \mathrm{~mW} \mathrm{~cm}^{-2}$ is slightly lower than that of the quinary-molten salt electrolyte, the ternary-molten salt also increases the electrochemical performance in the $\mathrm{Li}-\mathrm{CO}_{2}$ battery. The $\mathrm{Li}-\mathrm{CO}_{2}$ battery with quinary-molten salt further allows us to observe the long-term cycle capability. As shown in Fig. $4 \mathrm{~d}$, the results show stable discharge-charge plots over 100 cycles at a high-current density of $2.0 \mathrm{~A} \mathrm{~g}^{-1}$. We observed that the charge overpotential decreases as the number of cycles increases in Fig. 4d. One plausible explanation is the parasitic reaction between $\mathrm{Li}_{2} \mathrm{CO}_{3}$ and the carbon defect sites. Because most metal-gas batteries use the capacity cutoff for cycle measurement, a discharge product is formed on a fresh carbon surface every cycle, which causes a parasitic reaction and multiple plateaus during the charging process. Thus, to mitigate the effect of the carbon surface, we also monitored the second cycle after the potential cutoff operation at the first cycle and observed a single charging plateau, indicating that the carbon surface is important for reducing the parasitic reaction during the charging process (Supplementary Fig. 16).

Synthesis of Ru nanoparticles by using Joule heating. Further enhancement of the $\mathrm{Li}-\mathrm{CO}_{2}$ cell can be achieved by a carbon cathode with $\mathrm{Ru}$ catalyst, because previous reports of $\mathrm{Li}-\mathrm{CO}_{2}$ batteries by using aprotic electrolytes indicate that the cathode catalyst efficiently promotes the decomposition of $\mathrm{Li}_{2} \mathrm{CO}_{3}{ }^{18,24}$. 
a

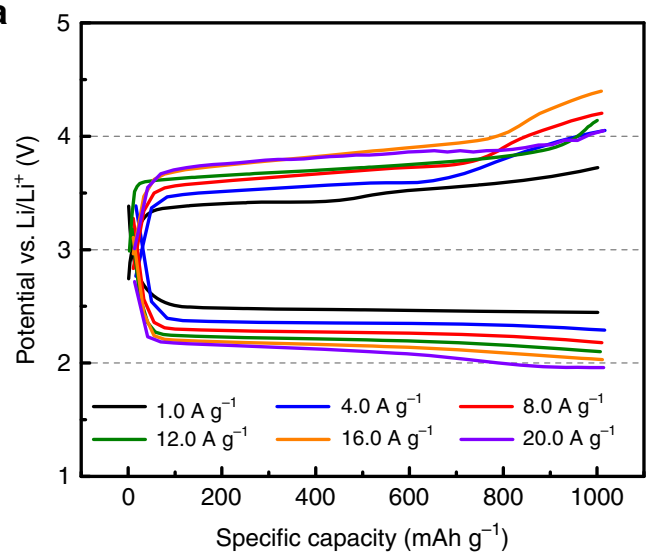

C

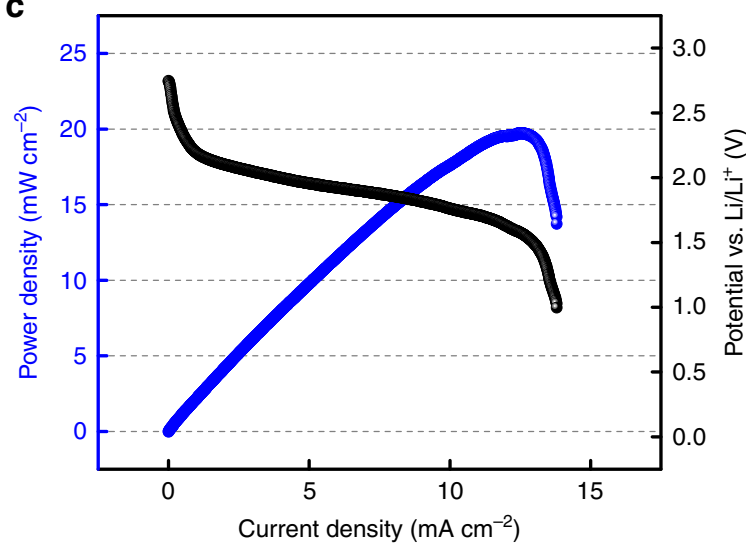

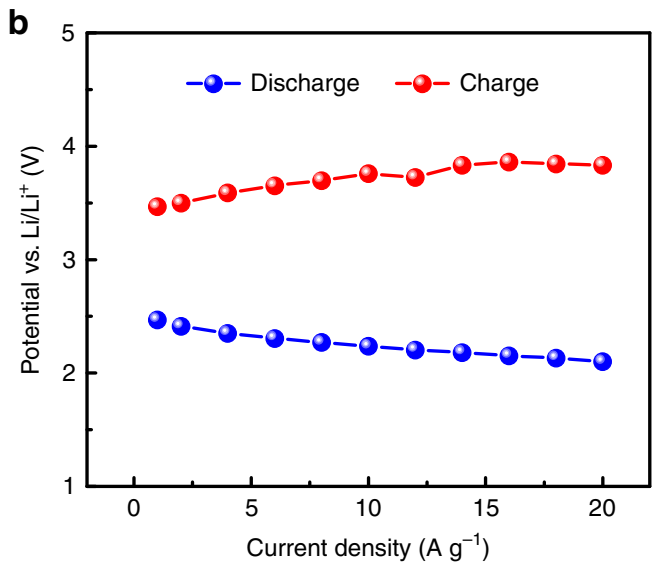

d

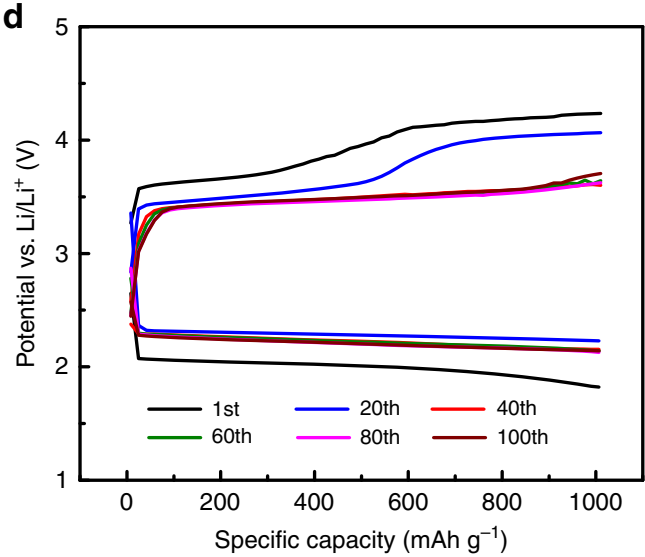

Fig. 4 Electrochemical performance of $\mathbf{L i}-\mathrm{CO}_{2}$ cell with quinary-molten salt electrolyte. a Galvanostatic discharge-charge profiles of the $\mathrm{Li}-\mathrm{CO}_{2}$ battery with quinary-molten salt electrolyte at different current densities from 1.0 to $20.0 \mathrm{~A} \mathrm{~g}^{-1}$ at $150^{\circ} \mathrm{C}$. b Plots of discharge-charge overpotential measured at $500 \mathrm{mAh} \mathrm{g}^{-1}$ as a function of current density. c Plots of operating voltage and power density versus current density of the $\mathrm{Li}_{-} \mathrm{CO}_{2}$ battery at $150{ }^{\circ} \mathrm{C}$ with scan rate of $0.01 \mathrm{~mA} \mathrm{~s}^{-1}$. d Galvanostatic discharge-charge profiles of a $\mathrm{Li}_{-} \mathrm{CO}_{2}$ cell with $2.0 \mathrm{~A} \mathrm{~g}^{-1}$ current density over up to 100 cycles.

As schematically shown in Fig. $5 \mathrm{a}, \mathrm{RuCl}_{3}$ in $\mathrm{H}_{2} \mathrm{O}$ solution was mixed thoroughly with Super $\mathrm{P}$ carbon powder by a Thinky mixer for $10 \mathrm{~min}$; then, the composite slurry was coated onto the carbon paper to apply the high current. In particular, the Joule heating method allows us not only to homogeneously disperse the $\mathrm{Ru}$ nanoparticles with a controlled size but also to reduce the thermal decomposition time of $\mathrm{RuCl}_{3}{ }^{36-38}$. After a systematic study of $\mathrm{Ru}$ nanoparticles with various particle sizes and populations (Fig. 5b (inset) and Supplementary Fig. 17), we found well-developed $\mathrm{Ru}$ nanoparticles on the carbon cathode from the optimum conditions of 2:1 weight ratio (Super P:Ru) slurry at $8 \mathrm{~A}$ for $1 \mathrm{~s}$. A high-resolution transmission electron microscopy (HRTEM) measurement further showed well-dispersed $\mathrm{Ru}$ particles on the carbon cathode (Fig. 5b). The magnified image in Fig. 5c shows the fringes of the crystalline structure of $\mathrm{Ru}$ nanoparticles, where the $d$-spacing of $0.21 \mathrm{~nm}$ represents the (101) plane of the $\mathrm{Ru}$ crystal ${ }^{39}$. Moreover, the energy-dispersive spectroscopy (EDS) mapping of $\mathrm{Ru}$ further supports the well-dispersed $\mathrm{Ru}$ nanoparticles on the carbon cathode surface in Fig. 5d (inset image is the mapping of the carbon element), confirming that the Joule heating method is a simple but potent way to develop the $\mathrm{Ru}$ catalyst, making it a suitable cathode for $\mathrm{Li}-\mathrm{CO}_{2}$ batteries without a polymeric binder ${ }^{40}$.

Synergistic effect of the molten salts and Ru nanoparticles. To evaluate the synergistic effect of the quinary-molten salts and $\mathrm{Ru}$ nanoparticles on the carbon cathode on the $\mathrm{Li}-\mathrm{CO}_{2}$ cell performance, we performed galvanostatic discharge-charge measurements with current density ranging from 1.0 to $20.0 \mathrm{Ag}^{-1}$ at $150{ }^{\circ} \mathrm{C}$ (Fig. 6a). The Ru nanoparticles on the carbon cathode were observed to further reduce the overpotential with a high discharge capacity to form a $\mathrm{Li}_{2} \mathrm{CO}_{3}$ discharge product $\left(44,000 \mathrm{mAh} \mathrm{g}^{-1}\right.$ at $10.0 \mathrm{Ag}^{-1}$ (Supplementary Figs. 18-19)). Although the proposed discharge reaction shows continuous consumption of $\mathrm{NO}_{3}{ }^{-}$during the discharge process, highly concentrated $\mathrm{NO}_{3}{ }^{-}$in the molten salt electrolyte does not significantly alter the electrochemical performance during the discharge process. In addition, the cell operates even at a high-current density of $20.0 \mathrm{~A} \mathrm{~g}^{-1}$ and enhances the $\mathrm{CO}_{2}$-capturing capacity, in contrast to the aprotic electrolyte-based $\mathrm{Li}-\mathrm{CO}_{2}$ battery with a Ru catalyst (Supplementary Fig. 20) ${ }^{24}$. We observed a sufficiently stable cycle capability of the $\mathrm{Li}-\mathrm{CO}_{2}$ battery at a current density at $2.0 \mathrm{Ag}^{-1}$ (Fig. 6b), $5.0 \mathrm{Ag}^{-1}$ (Fig. 6c), and $10.0 \mathrm{Ag}^{-1}$ (Fig. $6 \mathrm{~d}$ ) at $150^{\circ} \mathrm{C}$. In particular, the cells are sustained for over 300 cycles at $10.0 \mathrm{~A} \mathrm{~g}^{-1}$ without significant alteration of the voltage potential. Moreover, the $\mathrm{Ru}$ nanoparticles in quinary-molten salt exhibited a peak power density approximately two times that of quinary-molten salt without $\mathrm{Ru}$ nanoparticles, indicating that the synergistic effect of $\mathrm{Ru}$ nanoparticles further reduces the energy barrier during the electrochemical reaction of the $\mathrm{Li}-\mathrm{CO}_{2}$ battery (Fig. 6e). In particular, we theoretically revealed that the addition of the $\mathrm{Ru}$ surface induced the electron transfer from $\mathrm{CO}_{2}{ }^{-}$to $\mathrm{Ru}$ particles to stabilize $\mathrm{CO}_{2}^{-}$, reducing the energy of the thermodynamic barrier (i.e., overpotential) (Supplementary Figs. 21-23). Consequently, the power density of $\mathrm{Li}-\mathrm{CO}_{2}$ battery was enhanced. As summarized in Fig. 6f, the peak power density of $33.4 \mathrm{~mW} \mathrm{~cm}^{-2}$ is 13 times higher than that of the conventional $\mathrm{Li}-\mathrm{CO}_{2}$ battery with 
a
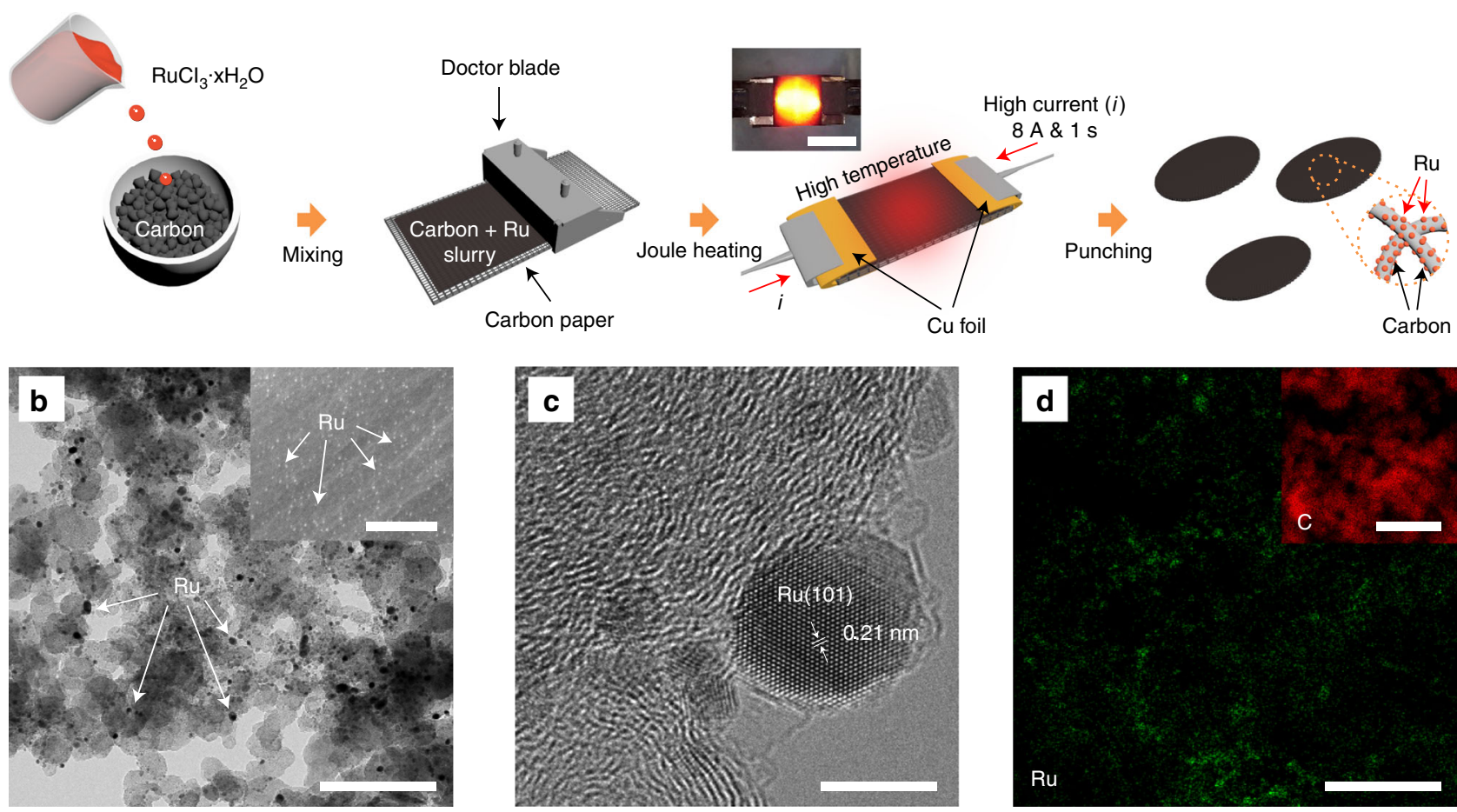

Fig. 5 Joule heating induced Ru nanoparticles. a Schematic illustration of the fabrication procedure of Ru nanoparticles on the carbon cathode by using the Joule heating method. The inset shows a photograph of light emitting from the carbon cathode during Joule heating. Scale bar is $1 \mathrm{~cm}$. $\mathbf{b}$ Bright-field TEM micrograph and SEM image (inset) of the carbon cathode with Ru nanoparticles after applying 8 A for $1 \mathrm{~s}$. Scale bars are $200 \mathrm{~nm}$. c High-resolution TEM image of Ru nanoparticles on the carbon cathode. Scale bar is $5 \mathrm{~nm}$. d EDS mapping of Ru and C (inset) elements of the TEM image in (b). Scale bars are $200 \mathrm{~nm}$.

a
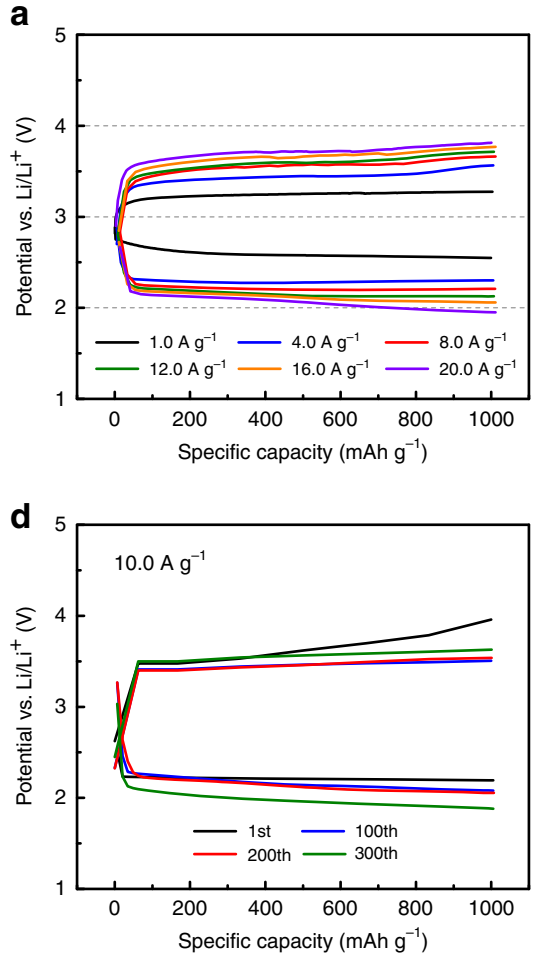

b

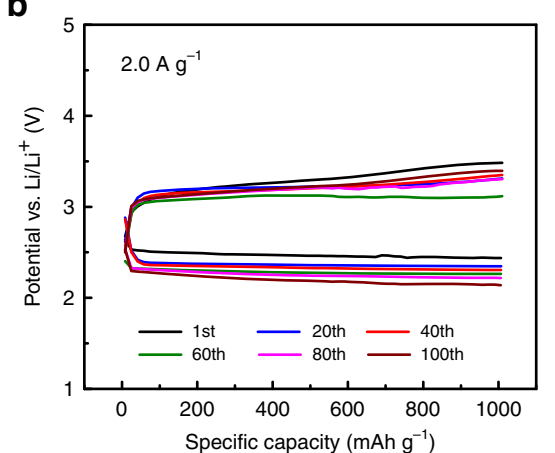

e

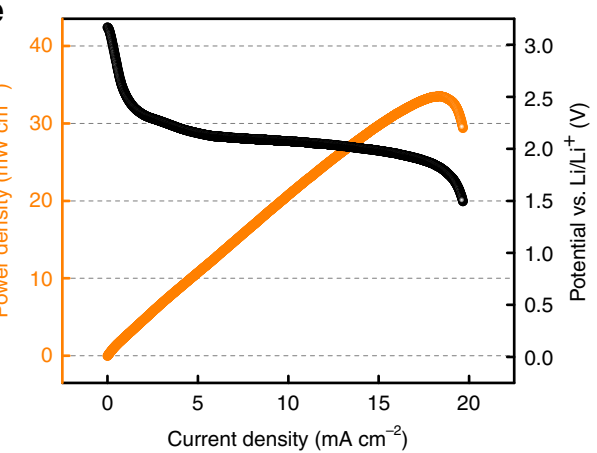

C

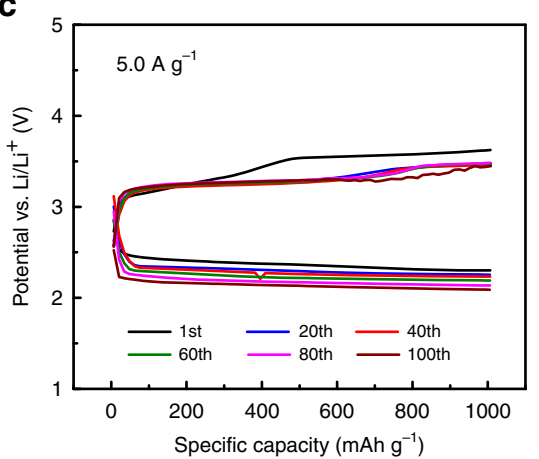

f

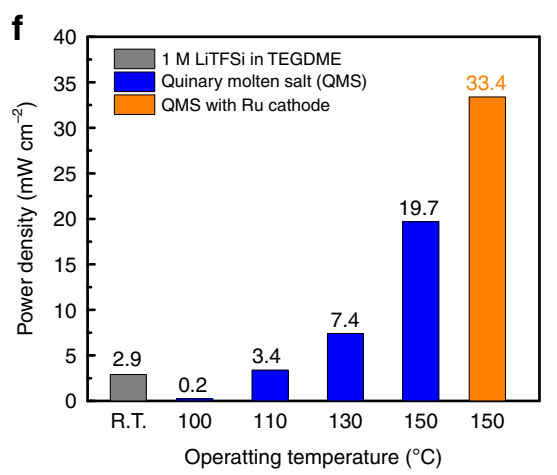

Fig. 6 Electrochemical performance of $\mathbf{L i}-\mathrm{CO}_{\mathbf{2}}$ cell by using molten salt and Ru nanoparticle. a Galvanostatic discharge-charge profiles of the $\mathrm{Li}-\mathrm{CO}{ }_{2}$ battery with quinary-molten salt electrolyte with a Ru nanoparticle cathode at different current densities from 1.0 to $20.0 \mathrm{Ag}^{-1}$ at $150{ }^{\circ} \mathrm{C}$. Cycling performance of the $\mathrm{Li}_{-} \mathrm{CO}_{2}$ battery at current rates of $2.0 \mathrm{Ag}^{-1}(\mathbf{b}), 5.0 \mathrm{Ag}^{-1}(\mathbf{c})$, and $10.0 \mathrm{~A} \mathrm{~g}^{-1}$ (d). e Polarization and power-density curves of quinarymolten salt electrolyte with the Ru nanoparticle cathode with a scan rate of $0.01 \mathrm{~mA} \mathrm{~s}^{-1}$. $\mathbf{f}$ Plots of peak power density of $1 \mathrm{M}$ LiTFSI in TEGDME (gray); quinary-molten salt at $100,110,130$, and $150^{\circ} \mathrm{C}$ (blue); quinary-molten salt electrolyte with a Ru nanoparticle cathode at $150^{\circ} \mathrm{C}$ (orange). 
the aprotic electrolyte (Supplementary Figs. 24-25), suggesting that the quinary-molten salts and the Ru nanoparticles on the carbon cathode make the $\mathrm{Li}-\mathrm{CO}_{2}$ cell a feasible high-performance $\mathrm{CO}_{2}$ capture and energy-storage system.

\section{Discussion}

We have demonstrated a high-performance $\mathrm{Li}-\mathrm{CO}_{2}$ cell based on the quinary-molten salt electrolyte with $\mathrm{Ru}$ nanoparticles on the carbon cathode. From the systematic DEMS investigation with in-depth theoretical investigation, we suggested a newly proposed decomposing reaction mechanism of the $\mathrm{Li}_{2} \mathrm{CO}_{3}$ compound in the nitrate-based molten salt at a high temperature. In addition, the synergistic effect of the quinary-molten salt and the welldistributed $\mathrm{Ru}$ catalyst on the carbon cathode allowed us to observe high-rate performance and long-term cycle capability over more than 300 cycles without significant alteration. The Li- $\mathrm{CO}_{2}$ battery ultimately achieved the highest peak power density of $33.4 \mathrm{~mW} \mathrm{~cm}{ }^{-2}$, confirming that the $\mathrm{Li}-\mathrm{CO}_{2}$ cell is suitable as a high-current-rate rechargeable battery and a highrate $\mathrm{CO}_{2}$ capture device.

\section{Methods}

Preparation of nitrate-based molten salt electrolyte. Lithium nitrate $\left(\mathrm{LiNO}_{3}\right)$, potassium nitrate $\left(\mathrm{KNO}_{3}\right)$, potassium nitrite $\left(\mathrm{KNO}_{2}\right)$, sodium nitrate $\left(\mathrm{NaNO}_{3}\right)$, calcium nitrate $\left(\mathrm{Ca}\left(\mathrm{NO}_{3}\right)_{2}\right)$, and cesium nitrate $\left(\mathrm{CsNO}_{3}\right)$ salts were purchased from Sigma-Aldrich (USA), with purity $\geq 99 \%$, and vacuum-dried at $60^{\circ} \mathrm{C}$ for $24 \mathrm{~h}$. We used a specific eutectic composition of $15 \mathrm{~mol} \% \mathrm{LiNO}_{3}, 30 \mathrm{~mol} \% \mathrm{KNO}_{3}, 30 \mathrm{~mol} \%$ $\mathrm{CsNO}_{3}, 10 \mathrm{~mol} \% \mathrm{NaNO}_{3}$, and $15 \mathrm{~mol} \% \mathrm{Ca}\left(\mathrm{NO}_{3}\right)_{2}$ for the quinary-molten salt, and $37 \mathrm{~mol} \% \mathrm{LiNO}_{3}, 39 \mathrm{~mol} \% \mathrm{KNO}_{2}$, and $24 \mathrm{~mol} \% \mathrm{CsNO}_{3}$ for the ternary-molten salt. The mixture was heated in a ceramic crucible with a torch ${ }^{32}$. The glass microfiber (GF) separator (GF/C, Whatman, UK) with diameter $16 \mathrm{~mm}$ was then dipped in the molten eutectic salt (eutectic temperatures, $T_{\mathrm{e}}: 75$ and $98^{\circ} \mathrm{C}$ for the quinary and ternary-molten salts, respectively, Supplementary Fig. 4) to infuse the GF separator and cooled to room temperature. The infused GF separator was dried at $\sim 50{ }^{\circ} \mathrm{C}$ in vacuum in an oven for $12 \mathrm{~h}$ and transferred into an Ar-filled glove box. The mass of the infused electrolyte was $\sim 160 \mathrm{mg}$.

Synthesis of Ru nanoparticles. Ruthenium(III) chloride hydrate $\left(\mathrm{RuCl}_{3} \cdot \mathrm{xH}_{2} \mathrm{O}\right.$, Sigma-Aldrich (USA)) solution ( $50 \mathrm{mg} \mathrm{ml}^{-1}$ in $\mathrm{H}_{2} \mathrm{O}$ ) was mixed with carbon (Super P, Timcal (Imerys Graphite \& Carbon), Switzerland) at a weight ratio of 2:1 (Super P:Ru) by a Thinky mixer for $10 \mathrm{~min}$. The homogenously mixed carbon with $\mathrm{Ru}$ solution was coated onto the carbon paper (AvCarb P50, FuelCellStore (USA)) using a doctor blade. The coated electrode was then dried at $120^{\circ} \mathrm{C}$ in a vacuum oven for $6 \mathrm{~h}$ to completely eliminate the residual solvent. The $\mathrm{RuCl}_{3}$-carbon electrodes were treated by electric Joule heating to form Ru nanoparticles on the carbon. To perform the Joule heating, the sample was connected to copper electrodes and electrically connected to an external power source (Regulated DC Power Supply TDP-3010B, TOYOTECH, Korea) in an argon-filled glove box. A current pulse of $8 \mathrm{~A}$ was applied through the sample, which created a Joule heating time of $1 \mathrm{~s}$. The loading mass of $\mathrm{Ru}$ on Super $\mathrm{P}(\mathrm{Ru}+$ Super $\mathrm{P})$ was $\sim 0.45 \mathrm{mg} \mathrm{cm}^{-2}$.

Li- $\mathrm{CO}_{2}$ cell assembly. For the preparation of the cathode for the aprotic electrolyte, the air cathode was fabricated using a mixture of Ketjen black carbon (EC$300 \mathrm{~J})$ or a carbon isotope (Carbon- ${ }^{13} \mathrm{C}$, Sigma-Aldrich (USA)) with a $60 \mathrm{wt} \%$ polytetrafluoroethylene (PTFE, Sigma-Aldrich, USA) binder at a weight ratio 9:1 (carbon:binder). The mixture was dispersed in water solution and cast on a SUS mesh (stainless-steel mesh, Shinmyung Science Inc.) current collector. The mixture was dried overnight at $120^{\circ} \mathrm{C}$ in a vacuum oven to eliminate the residual solvents. The cathode-loading mass was $\sim 0.3 \mathrm{mg} \mathrm{cm}^{-2}$.

For the preparation of cathodes for the quinary-molten salt electrolyte, Super $\mathrm{P}$ porous carbon was homogeneously mixed with a $60 \mathrm{wt} \%$ PTFE binder (weight ratio $=9: 1$ ) in a water solution. A P50 carbon cathode was then coated with the Super P mixture using a doctor blade, and the coated electrode was then dried at $120^{\circ} \mathrm{C}$ in a vacuum oven for $6 \mathrm{~h}$ to completely eliminate the residual solvent. The loading mass weight of Super P carbon was $\sim 0.45 \mathrm{mg} \mathrm{cm}^{-2}$.

In all, $1 \mathrm{M}$ LiTFSI in the TEGDME was purchased from Enchem (Korea) and stored in an Ar-filled glove box with moisture and oxygen levels of $<1 \mathrm{ppm}$. The $\mathrm{Li}-\mathrm{CO}_{2}$ cell was assembled into a 2032-format coin cell (Hohsen, CR2032, Japan) containing 30 holes with diameters of $1 \mathrm{~mm}$ for the $\mathrm{Li}-\mathrm{CO}_{2}$ electrochemical test. The pure-Li metal anode with thickness of $300 \mu \mathrm{m}$ was purchased from FMC (Korea) and used as received. The GF separator was dried overnight at $150{ }^{\circ} \mathrm{C}$ in a vacuum oven. The cell fabrication was carried out in an $\mathrm{Ar}$ atmosphere $\left(\mathrm{H}_{2} \mathrm{O}\right.$ and $\mathrm{O}_{2}<1 \mathrm{ppm}$ ). A quinary- or ternary-molten-salt-based $\mathrm{Li}-\mathrm{CO}_{2}$ cell was fabricated by placing an electrolyte-infused GF separator on Li metal having a diameter of $11 \mathrm{~mm}$ using a 2032 coin cell with 30 holes with diameters of $1 \mathrm{~mm}$. Li metal/ electrolyte-infused GF separator/carbon cathode cells were pressurized by using a crimping machine.

Material characterization. The morphology of the Ru nanoparticles on the carbon cathode was characterized using high-resolution transmission electron microscopy (HR-TEM; JEM-2100F, JEOL, Japan) at an accelerating voltage of $200 \mathrm{kV}$. The discharge products for carbon with and without the Ru nanoparticle cathode were analyzed by using a scanning electron microscope (SEM; S-4800, Hitachi High Technologies, Japan) at an acceleration voltage of $5.0 \mathrm{kV}$, and X-ray photoelectron spectroscopy (XPS) experiments were performed on a scanning X-ray microprobe (ESCALAB 250XI, Thermo Fisher Scientific, USA). The Raman spectrum data were collected using a confocal Raman (WITec, Alpha 300R, $532 \mathrm{~nm}$ ) system with an acceleration voltage of $1.0 \mathrm{eV}$. For the post-discharge analysis of the electrodes, the disassembled cathodes from the cells were then packed in an Ar-filled glove box before they were transferred to the SEM chamber or Raman spectrometer.

Electrochemical measurements. Galvanostatic cycling at various current densities $\left(0.05-20.0 \mathrm{~A} \mathrm{~g}^{-1}\right)$ and power analysis were used to evaluate battery performance (capacity, voltage, and power density) by using a computer-controlled battery measurement system (WBCS 3000, WonATech, Korea and VMP3 Multichannel Workstation, BioLogic). For the experiments performed, the aprotic electrolytes were tested at room temperature, and the quinary-molten salt electrolyte was tested at various operating temperatures $\left(100-150{ }^{\circ} \mathrm{C}\right)$ in a lab-built heating kit. The details of the differential electrochemical mass spectrometer (DEMS) system are described elsewhere ${ }^{41}$. Prior to measurement of the electrochemical performance of the quinary-molten-salt-based $\mathrm{Li}-\mathrm{CO}_{2}$ battery, the cell was maintained at a constant temperature $\left(100-150^{\circ} \mathrm{C}\right)$ to fully impregnate the quinary salt and stabilize the gas pressure (1050 Torr). Carbon dioxide gas with an isotope of carbon $\left({ }^{13} \mathrm{CO}_{2}\right)$ was purchased from Cambridge Isotope Laboratories, Inc. The input power required to maintain a temperature of $150^{\circ} \mathrm{C}$ was $\sim 0.6 \mathrm{~mW}$.

\section{Data availability}

The data that support the findings of this study are available from the corresponding author upon request.

Received: 20 June 2019; Accepted: 16 December 2019; Published online: 23 January 2020

\section{References}

1. Girishkumar, G., McCloskey, B., Luntz, A. C., Swanson, S. \& Wilcke, W. Lithium-air battery: promise and challenges. J. Phys. Chem., Lett. 1, 2193-2203 (2010).

2. Bruce, P. G., Freunberger, S. A., Hardwick, L. J. \& Tarascon, J. -M. Li- $\mathrm{O}_{2}$ and Li-S batteries with high energy storage. Nat. Mater. 11, 19-29 (2012).

3. Lu, J. et al. Aprotic and aqueous $\mathrm{Li}_{-} \mathrm{O}_{2}$ batteries. Chem. Rev. 11, 5611-5640 (2014).

4. Kang, S. J., Mori, T., Narizuka, S., Wilcke, W. \& Kim, H. -C. Deactivation of carbon electrode for elimination of carbon dioxide evolution from rechargeable lithium-oxygen cells. Nat. Commun. 5, 3937 (2014).

5. Qiao, Y. et al. $\mathrm{Li}-\mathrm{CO}_{2}$ electrochemistry: a new strategy for $\mathrm{CO}_{2}$ fixation and energy storage. Joule 1, 359-370 (2017).

6. Zhou, J. et al. A quasi-solid-state flexible fiber-shaped $\mathrm{Li}-\mathrm{CO}_{2}$ battery with low overpotential and high energy efficiency. Adv. Mater. 31, 1804439 (2018).

7. Zhang, Z. et al. Verifying the rechargeability of $\mathrm{Li}-\mathrm{CO}_{2}$ batteries on working cathodes of Ni nanoparticles highly dispersed on $\mathrm{N}$-doped graphene. Adv. Sci. 5, 1700567 (2018)

8. Xing, Y. et al. Crumpled Ir nanosheets fully covered on porous carbon nanofibers for long-life rechargeable Lithium- $\mathrm{CO}_{2}$ batteries. $A d v$. Mater. 30, 1803124 (2018).

9. McCloskey, B. D. et al. Twin problems of interfacial carbonate formation in nonaqueous $\mathrm{Li}_{-} \mathrm{O}_{2}$ batteries. J. Phys. Chem. Lett. 3, 997-1001 (2012).

10. Ottakam Thotiyl, M. M., Freunberger, S. A., Peng, Z. \& Bruce, P. G. The carbon electrode in nonaqueous $\mathrm{Li}-\mathrm{O}_{2}$ cells. J. Am. Chem. Soc. 135, 494-500 (2013).

11. McCloskey, B. D. et al. Limitations in rechargeability of $\mathrm{Li}^{-} \mathrm{O}_{2}$ batteries and possible origins. J. Phys. Chem. Lett. 3, 3043-3047 (2012).

12. Giordani, V. et al. A molten salt lithium-oxygen battery. J. Am. Chem. Soc. 138, 2656-2663 (2016).

13. Peng, Z., Freunberger, S. A., Chen, Y. \& Bruce, P. G. A reversible and higherrate $\mathrm{Li}_{2} \mathrm{O}_{2}$ battery. Science 337, 1223985 (2012).

14. Zhao, Z., Huang, J. \& Peng, Z. Achilles' Heel of lithium-air batteries: Lithium carbonate. Angew. Chem. Int. Ed. 57, 3874-3886 (2018).

15. Zhang, $\mathrm{X}$. et al. Rechargeable $\mathrm{Li}-\mathrm{CO}_{2}$ batteries with carbon nanotubes as air cathode. Chem. Commun. 51, 14636-14639 (2015). 
16. $\mathrm{Li}, \mathrm{C}$. et al. A rechargeable $\mathrm{Li}-\mathrm{CO}_{2}$ battery with a gel polymer electrolyte. Angew. Chem. Int. Ed. 56, 9126-9130 (2017).

17. $\mathrm{Hu}, \mathrm{X} ., \mathrm{Li}, \mathrm{Z} . \&$ Chen, J. Flexible $\mathrm{Li}-\mathrm{CO}_{2}$ batteries with liquid-free electrolyte. Angew. Chem. Int. Ed. 129, 5879-5883 (2017).

18. Yang, $\mathrm{S}$. et al. A reversible lithium- $\mathrm{CO}_{2}$ battery with $\mathrm{Ru}$ nanoparticles as a cathode catalyst. Energy Environ. Sci. 10, 972-978 (2017).

19. Liu, B. et al. Recent advances in understanding $\mathrm{Li}-\mathrm{CO}_{2}$ electrochemistry. Energy Environ. Sci. 12, 887-922 (2019).

20. Wang, Q., Luo, J., Zhong, Z. \& Borgna, A. $\mathrm{CO}_{2}$ capture by solid adsorbents and their applications: current status and new trends. Energy Environ. Sci. 4, 42-55 (2011).

21. Liu, Y., Wang, R., Lyu, Y., Li, H. \& Chen, L. Rechargeable Li/CO $\mathrm{CO}_{2}-\mathrm{O}_{2}(2: 1)$ battery and $\mathrm{Li} / \mathrm{CO}_{2}$ battery. Energy Environ. Sci. 7, 677-681 (2014).

22. Zhang, Z. et al. The first introduction of graphene to rechargeable $\mathrm{Li}-\mathrm{CO}_{2}$ batteries. Angew. Chem. Int. Ed. 57, 6550-6553 (2015).

23. Qie, L., Lin, Y., Connell, J. W., Xu, J. \& Dai, L. Highly rechargeable lithium$\mathrm{CO}_{2}$ batteries with a boron- and nitrogen-codoped holey-graphene cathode. Angew. Chem. Int. Ed. 56, 6970-6974 (2017).

24. Qiao, Y. et al. Transient, in situ synthesis of ultrafine ruthenium nanoparticles for a high-rate $\mathrm{Li}-\mathrm{CO}_{2}$ battery. Energy Environ. Sci. 12, 1100-1107 (2019).

25. Yin, W., Grimaud, A., Azcarate, I., Yang, C. \& Tarascon, J.-M. Electrochemical reduction of $\mathrm{CO}_{2}$ mediated by quinone derivatives: implication for $\mathrm{Li}-\mathrm{CO}_{2}$ battery. J. Phys. Chem. C. 122, 6546-6554 (2018).

26. $\mathrm{Li}$, J. et al. Drawing a pencil-trace cathode for a high-performance polymer-based $\mathrm{Li}-\mathrm{CO}_{2}$ battery with redox mediator. Adv. Funct. Mater. 29, 1806863 (2019).

27. Zhang, $\mathrm{X}$. et al. High performance $\mathrm{Li}-\mathrm{CO}_{2}$ batteries with $\mathrm{NiO}-\mathrm{CNT}$ cathodes. J. Mater. Chem. A 6, 2792-2796 (2018).

28. Ma, W., Lu, S., Lei, X., Liu, X. \& Ding, Y. Porous $\mathrm{Mn}_{2} \mathrm{O}_{3}$ cathode for highly durable Li- $\mathrm{CO}_{2}$ batteries. J. Mater. Chem. A 6, 20829-20835 (2018).

29. Yang, S., He, P. \& Zhou, H. Exploring the electrochemical reaction mechanism of carbonate oxidation in $\mathrm{Li}-\mathrm{air} / \mathrm{CO}_{2}$ battery through tracing missing oxygen. Energy Environ. Sci. 9, 1650-1654 (2016).

30. Walker, W. et al. A rechargeable $\mathrm{Li}-\mathrm{O}_{2}$ battery using a lithium nitrate/N,N dimethylacetamide electrolyte. J. Am. Chem. Soc. 135, 2076-2079 (2013).

31. Ahn, S. M. et al. High-performance lithium-oxygen battery electrolyte derived from optimum combination of solvent and lithium salt. Adv. Sci. 4, 1700235 (2017).

32. Raade, J. W. \& Padowitz, D. Development of molten salt heat transfer fluid with low melting point and high thermal stability. J. Sol. Energy Eng. 133, 031013 (2011)

33. Uddin, J. et al. Lithium nitrate as regenerable SEI stabilizing agent for rechargeable Li/O $\mathrm{O}_{2}$ batteries. J. Phys. Chem. Lett. 4, 3760-3765 (2013).

34. Jaumann, T. et al. Role of 1, 3-dioxolane and $\mathrm{LiNO}_{3}$ addition on the long term stability of nanostructured silicon/carbon anodes for rechargeable lithium batteries. J. Electrochem. Soc. 163, A557-A564 (2016).

35. Baek, K. et al. Chemically impregnated $\mathrm{NiO}$ catalyst for molten electrolyte based gas-tank-free $\mathrm{Li}-\mathrm{O}_{2}$ battery. J. Power Sources 402, 68-74 (2018).

36. Yao, Y. et al. Carbothermal shock synthesis of high-entropy-alloy nanoparticles. Science 359, 1489-1494 (2018).

37. Yang, C. et al. Ultrafine silver nanoparticles for seeded lithium deposition toward stable lithium metal anode. Adv. Mater. 29, 1702714 (2017).

38. Yao, Y. et al. In situ high temperature synthesis of single-component metallic nanoparticles. ACS Cent. Sci. 3, 294-301 (2017).

39. Feng, Y., Yang, J., Liu, H., Ye, F. \& Yang, J. Selective electrocatalysts toward a prototype of the membraneless direct methanol fuel cell. Sci. Rep. 4, 3813 (2014).

40. Yao, Y. et al. Carbon welding by ultrafast Joule heating. Nano Lett. 16, 7282-7289 (2016).
41. McCloskey, B. D., Bethune, D. S., Shelby, R. M., Girishkumar, G. \& Luntz, A. C. Solvents' critical role in nonaqueous lithium-oxygen battery electrochemistry. J. Phys. Chem. Lett. 2, 1161-1166 (2011).

\section{Acknowledgements}

This work was supported by "Human Resources Program in Energy Technology" of the Korea Institute of Energy Technology Evaluation and Planning (KETEP), granted financial resource from the Ministry of Trade, Industry \& Energy, Republic of Korea (No. 20194010201890), and C1 Gas Refinery Program through the National Research Foundation of Korea (NRF) funded by the Ministry of Science and ICT (NRF2018M3D3A1A01055761)

\section{Author contributions}

K.B. carried out most of the experimental work and characterization. W.C.J., J.C.K., and S.K.K. performed theoretical calculation. S.W. contributed to cell fabrication. J.G.L. and K.A. synthesized the nanoparticles and performed TEM measurement. K.A. and S.K.K. provided comments and conceived the project. S.J.K. supervised the project and analyzed the data. S.J.K and S.K.K. wrote the paper, and all authors discussed the results and commented on the paper.

\section{Competing interests}

The authors declare no competing interests.

\section{Additional information}

Supplementary information is available for this paper at https://doi.org/10.1038/s41467019-14121-1.

Correspondence and requests for materials should be addressed to K.A., S.K.K. or S.J.K

Peer review information Nature Communications thanks Xingbin Yan and other, anonymous, reviewers for their contributions to the peer review of this work.

Reprints and permission information is available at http://www.nature.com/reprints

Publisher's note Springer Nature remains neutral with regard to jurisdictional claims in published maps and institutional affiliations.

Open Access This article is licensed under a Creative Commons Attribution 4.0 International License, which permits use, sharing, adaptation, distribution and reproduction in any medium or format, as long as you give appropriate credit to the original author(s) and the source, provide a link to the Creative Commons license, and indicate if changes were made. The images or other third party material in this article are included in the article's Creative Commons license, unless indicated otherwise in a credit line to the material. If material is not included in the article's Creative Commons license and your intended use is not permitted by statutory regulation or exceeds the permitted use, you will need to obtain permission directly from the copyright holder. To view a copy of this license, visit http://creativecommons.org/ licenses/by/4.0/

(C) The Author(s) 2020 